\title{
First isolation of Vibrio furnissii (emerging Vibrio) from mussels (Mediterranean mussel and bearded mussel) in Turkey
}

\author{
İlker ÇAMKERTEN, Meriç Lütfi AVSEVER, Adil AKSOY
}

Aksaray University, Eskil Vocation of High School, Laboratory and Veterinary Sciences, Aksaray, Turkey.

\begin{abstract}
Summary: Vibrio furnissii is an emerging pathogen that can cause acute gastroenteritis in humans. In this work, 652 bivalve mollusc samples (wedge shell-Donax trunculus, L.1758, oyster-Ostrea edulis, L.1758, cockle-Venus verrucosa, L.1758, clam-Tapes decussatus, L.1758, bearded mussel-Modiolus barbatus, L.1758, Mediterranean mussel-Mytilus galloprovincialis L.1819, striped venus-Chamelea gallina L.1753) sent to the laboratory from stations in Ayval1k and Balıkesir (Northern Aegean Region of Turkey) between 2007-2010 were researched with conventional microbiological methods and six isolates were identified as Vibrio furnisii. Isolates were later confirmed with PCR using primers specific to toxR gene. Isolation rate of $V$. furnisii from bivalve molluscs per years were 2007 (2\%), $2008(0.43 \%), 2009$ (1.29\%), $2010(0 \%)$ and per shell fish species were mediterranean mussel (3.33\%), bearded mussel $(3.27 \%)$, oyster $(3.27 \%)$, clam $(0 \%)$, cockle $(0 \%)$, wedge shell $(0 \%)$, striped venus $(0 \%)$. In this work, $V$. furnissi was isolated from mussels in Turkey for the first time and attention was drawn zoonotic importance of the agent.
\end{abstract}

Keywords: Bearded mussel, emerging Vibrio, Mediterranean mussel, Vibrio furnissii.

\section{Türkiye'deki midyelerden (Kara midye ve kıllı midye) ilk Vibrio furnissii (emerging Vibrio) izolasyonu}

Özet: Vibrio furnissii insanlarda akut gastroenteritise sebep olan ve önemi gittikçe artan bir patojendir. Bu çalışmada, 20072010 yılları arasında, Ayvalık ve Balıkesir'deki (Türkiye'nin Kuzey Ege bölgesi) istasyonlardan laboratuvara gönderilmiş 652 takım çift kabuklu yumuşakça (kum şırlanı-Donax trunculus, L. 1758, yassı istiridye-Ostrea edulis, L. 1758, kidonya-Venus verrucosa, L. 1758, akivades-Tapes decussatus, L. 1758, k1ll midye -Modiolus barbatus, L. 1758, kara midye - Mytilus galloprovincialis L. 1819, kum midyesi, Chamelea gallina L.1753) konvansiyonel mikrobiyolojik yöntemlerle araştırıldı ve çalışmada izole edilen altı izolatın $V$. furnissi olduğu tespit edildi. İzolatlar daha sonra toxR genine spesifik primerler kullanılarak PCR ile konfirme edildi. Çalışmada kullanılan çift kabuklu yumuşakçalardan $V$. furnissii izolasyon oranı yıl ve tür bazında 2007 (\% 2), 2008 (\% 0.43), 2009 (\% 1.29), 2010 $(\% 0)$; kara midye (\% 3.33), kıllı midye (\% 3.27), istiridye (\% 3.27), akivades (\% 0), kidonya ( $\% 0)$, kum şılanı ( $\% 0)$, kum midyesi (\% 0) olarak tespit edildi. Bu çalışmada Türkiye'deki midyelerden ilk kez $V$. furnissi izole edilmiş olup, etkenin zoonotik önemi vurgulanmıştır.

Anahtar sözcükler: Emerging Vibrio, kara midye, k1llı midye, Vibrio furnissii.

\section{Introduction}

Vibrio furnissii, which is a gram negative halophyllic bacterium, was originally thought to be an aerogenic (able to produce gas from glucose) strain of Vibrio fluvialis. $\mathrm{V}$. fluvialis and $V$. furnissii were first described in 1977 after isolation from diarrheic patients and from environmental sources (14). In 1983, however, V. furnissii was shown to be a distinct species by genetic analysis $(19,20)$. It consists of two circular chromosomes $(3.2 \mathrm{Mb}, 1.6 \mathrm{Mb})$ and reveals novel genes likely to be involved in pathogenicity (7).

$V$. furnissii unlike $V$. cholerae, V. parahaemolyticus and V. vulnificus is not a lethal human pathogen (7). Still, $V$. furnissii is classified as an "emerging vibrio" $(16,17$, 21 ), which can be pathogenic for humans and has been implicated in occasional outbreaks of acute gastroenteritis in which mortalities have been reported $(9,10,25,34)$. Recent studies have shown that $V$. furnisii, as a result of climate change, is a potential threat especially to people living in developing tropical coastal areas (21). V. furnissii is also capable of causing infections in bivalve molluscs and other aquatic organisms and posesses various virulence factors $(1,3,24)$.

Conventional microbiological methods are frequently used in the identification of $V$. furnissii $(8,16)$. Molecular methods such as PCR are reported to be faster with lower costs and are also less laborious. Still, during identification with conventional and molecular methods $V$. furnisii has to be discriminated from V. fluvialis $(19,33)$. Primers developed by Schirmeister et al. (28) targeting a specific region in the toxR gene successfully discriminates between $V$. furnisii and $V$. fluvialis as well as 41 members 
of the Vibrio genus. ToxR gene is involved in the regulation of virulence-associated genes in several Vibrio species $(23,27)$.

Incidence of $V$. furnissi in bivalve molluscs is less than that of $V$. parahaemolyticus and $V$. alginolyticus. Matte et al. (24), reported the incidence of various Vibrio spp. isolated from oysters to be $V$. alginolyticus (81\%), V. parahaemolyticus (77\%), V. cholerae non-01 (31\%), V. fluvialis (27\%), V. furnissii (19\%), V. mimicus (12\%), and V. vulnificus (12\%), respectively. However, V. furnissii was often isolated from human feces $(10,15,21)$. Demir (11), has been reported of $V$. furnissi isolated from oyster in Turkey but there have yet been no reports of $V$. furnisii isolated from musels in Turkey. The aim of this work is to investigate the presence of $V$. furnissii from bivalve molluscs and to draw attention to the zoonotic importance of this pathogen.

\section{Materials and Methods}

In this work, 652 bivalve mollusc sample groups sent from production stations to the laboratory between 2007 2010 (wedgeshell-Donax trunculus, L.1758, oyster-Ostrea edulis, L.1758, cockle-Venus verrucosa, L.1758, clamTapes decussatus, L.1758, bearded mussel-Modiolus barbatus, L.1758, Mediterranean mussel-Mytilus galloprovincialis L.1819, striped venus-Chamelea gallina, L.,1753) were used. Sampling was done throughout the year with the exception of summer (May $1^{\text {st }}$-August $31^{\text {st }}$ ) when shellfish collection was prohibited. Average water temperature was $20^{\circ} \mathrm{C}\left( \pm 2{ }^{\circ} \mathrm{C}\right)$ during sampling seasons. Samples were sent to the lab after being seperated and grouped according to species.

Isolation and identification: For pre-enrichment bivalve mollusc tissue homogenates were inoculated into Saline Water (ASP) and were incubated at $37^{\circ} \mathrm{C}$ for 18-24 hours. Inoculations were made on ThiosulfateCitrate-Bile salts-Sucrose (TCBS) (Sigma-Aldrich) agar from this enrichment. After 24 hour incubation at $37^{\circ} \mathrm{C}$, the colonies oxidase positive and yellowish color in TCBS were investigated further with conventional methods (4, $16,18)$. Accordingly, isolates positive for methyl red (1\% $\mathrm{NaCI}$, arginine (1\% NaCI), citrate (Simmons) test, glucose, mannose and sucrose fermentation, gas production in glucose, growth at 25 and $37^{\circ} \mathrm{C}$ and negative for Voges-Proskauer $(1 \% \mathrm{NaCI})$, indole $(1 \% \mathrm{NaCI}), \mathrm{H}_{2} \mathrm{~S}$ on Triple Sugar Iron (TSI) $(1 \% \mathrm{NaCI})$, urea (1\% NaCI) (Sigma-Aldrich), lysine $(1 \% \mathrm{NaCI})$, ornithine $(1 \% \mathrm{NaCI})$ were identified as $V$. furnissii.

Confirmation with PCR: DNA extraction was carried out from six isolates with a commercial kit (High Pure PCR Template Preparation Kit- Rosche Life Science, Germany; Lot: 11054300) previously identified as $V$. furnissii with conventional microbiology and grown on Tryptic Soy
Agar (TSA) (Sigma-Aldrich) according to the manufacturer's instructions. tox $R$ was determined to be the target gene for confirmation and the PCR protocol reported by Schirmeister et al. (27) was used. V. furnissii ATCC 35016 was used as a positive control, $V$. anguillarum ATCC 19264 was the negative control. The primer sequences were Vfurn-toxR2-fo AGACGCTGATCTCGATCCAC and Vfurn-toxR2-re TTGTCAAAGACCGCCAGAC. PCR amplification was performed in a $25 \mu$ l volume with $1 \times$ PCR buffer $(2 \mathrm{mM}$ $\mathrm{MgCl}_{2}$ ), $0.2 \mathrm{mM}$ of each deoxynucleoside triphosphate (dNTP), $0.2 \mu \mathrm{M}$ of each primer, 1.5 U Taq DNA polymerase (MBI, Fermantas) and 2 ng of template DNA. The toxR PCR assay specific for $V$. furnissii was performed for 30 cycles at $94^{\circ} \mathrm{C}$ for $30 \mathrm{~s}, 60^{\circ} \mathrm{C}$ for $30 \mathrm{~s}$, and $72^{\circ} \mathrm{C}$ for $20 \mathrm{~s}$ preceded by an initial incubation at $94^{\circ} \mathrm{C}$ for $5 \mathrm{~min}$ and followed by a final extension step at $72^{\circ} \mathrm{C}$ for $7 \mathrm{~min}$ (Techne, TC-412). After PCR amplification, 4 $\mu l$ of each product was added into a $1.0 \%$ agarose gel, electrophoresed (Thermo, Primo ${ }^{\mathrm{TM}}$ ). DNA size marker 100 DNA Ladder (MBI Fermentas) was used. Bands were visualised with designated equipment (Vilber Lourmant, E-BOX VX5).

\section{Results}

From 652 shellfish sample groups used in this research $V$. furnissii was isolated from six (0.92\%). Information on bivalve molluscs from which the isolates were obtained are supplied in Table 1. Phenotypic properties of isolates are in Table 2 and gel electrophoresis of PCR confirmation is supplied in Figure 1. V. furnissii isolation rates according to year and species are as follows; 2007 (2\%), 2008 (0.43\%), 2009 (1.29\%), 2010 $(0 \%)$; mediterranean mussel $(3.33 \%)$, bearded mussel $(3.27 \%)$, oyster $(3.27 \%)$, clam $(0 \%)$, cockle $(0 \%)$, wedge shell $(0 \%)$, striped venus $(0 \%)$.

As a result of this work, 652 bivalve mollusc samples from production stations in Ayvalık and Balikesir provinces of Turkey between 2007-2010 were investigated with conventional and molecular methods and six isolates (2 Bearded mussels, 2 Mediterranean mussels, 2 oysters ) were identified as $V$. furnisii.

\section{Discussion and Conclusion}

Food-borne infections and toxications due to the consumption of raw or under-cooked shellfish are common. The symptoms seen in these cases are mainly, abdominal cramps, sicknes, vomiting, fever and severe headache (12). Within lethal human pathogens isolated from shellfish and which cause food infection. $V$. cholerae, V. parahaemolyticus and V. vulnificus comes first (7). V. furnissii on the other hand is an "emerging vibrio" and its pathogenicity in humans is open to debate. 
Table 1. Information on bi-valve mollusc samples from which $V$. furnisii were isolated and number of isolates.

Tablo 1. V. furnissii izole edilen çift kabuklu yumuşakçalara ait bilgiler ve izolasyon sayıları

\begin{tabular}{|c|c|c|c|c|c|c|c|c|c|c|c|c|}
\hline & \multicolumn{3}{|c|}{2007} & \multicolumn{3}{|c|}{2008} & \multicolumn{3}{|c|}{2009} & \multicolumn{3}{|c|}{2010} \\
\hline & $\mathrm{T}^{*}$ & $\mathrm{P}^{* *}$ & $\mathrm{~N} * * *$ & $\mathrm{~T}$ & $\mathrm{P}$ & $\mathrm{N}$ & $\mathrm{T}$ & $\mathrm{P}$ & $\mathrm{N}$ & $\mathrm{T}$ & $\mathrm{P}$ & $\mathrm{N}$ \\
\hline Clam & 44 & - & - & 48 & - & - & 44 & - & - & 37 & - & - \\
\hline Mediterranean mussel & 43 & 2 & $\begin{array}{c}\text { MR } \\
(3,4)\end{array}$ & 14 & - & - & - & - & - & 3 & - & - \\
\hline Oyster & 50 & 1 & MR 5 & 50 & 1 & MR 6 & 61 & - & - & - & - & - \\
\hline Bearded mussel & 23 & 1 & MR 1 & 24 & - & - & 14 & 1 & MR 2 & - & - & - \\
\hline Cockle & 22 & - & - & 24 & - & - & 22 & - & - & 20 & - & - \\
\hline Wedge Shell & - & - & - & 13 & - & - & 13 & - & - & 7 & - & - \\
\hline Striped venus & 18 & - & - & 58 & - & - & - & - & - & - & - & - \\
\hline Total & 200 & 4 & & 231 & 1 & & 154 & 1 & & 67 & & \\
\hline Distrubition of isolation (\%) & $2 \%$ & & & $0.43 \%$ & & & $1.29 \%$ & & & $0 \%$ & & \\
\hline
\end{tabular}

$\mathrm{T}^{*}$ Bivalve mollusc samples $\mathrm{P}^{* *}: V$. furnissii positive bivalve mollusc samples $\mathrm{N}^{* * *}$ Isolate names.

Table 2. Phenotypic properties of $V$. furnissii isolates.

Tablo 2. V. furnissii izolatlarının fenotipik özellikleri.

\begin{tabular}{|c|c|c|c|c|c|c|}
\hline Strains & MR 1 & MR 2 & MR 3 & MR 4 & MR 5 & MR 6 \\
\hline Source of isolation & $\begin{array}{l}\text { Berded } \\
\text { mussel }\end{array}$ & $\begin{array}{l}\text { Berded } \\
\text { Mussel }\end{array}$ & Mediterraneanmussel & Mediterraneanmussel & Oyster & Oyster \\
\hline Gram stain & - & - & - & - & - & - \\
\hline Oxidase production & + & + & + & + & + & + \\
\hline Motilite & + & + & + & + & + & + \\
\hline Growth on TCBS media & + , yellow & + , yellow & + , yellow & + , yellow & + , yellow & + , yellow \\
\hline Utilization of citrate & + & + & + & + & + & + \\
\hline Utilization of glucose ( $1 \% \mathrm{NaCI})$ & + & + & + & + & + & + \\
\hline Utilization of sucrose ( $1 \% \mathrm{NaCI})$ & + & + & + & + & + & + \\
\hline Utilization of arabinose $(1 \% \mathrm{NaCI})$ & + & + & + & + & + & + \\
\hline Utilization of lactose $(1 \% \mathrm{NaCI})$ & - & - & - & - & - & - \\
\hline Gas production from glucose & + & + & + & + & + & + \\
\hline Voges-Proskauer reaction & - & - & - & - & - & - \\
\hline Methyl red $(1 \% \mathrm{NaCI})$ & + & + & + & + & + & + \\
\hline Arginine $(1 \% \mathrm{NaCI})$ & + & + & + & + & + & + \\
\hline Ornithine $(1 \% \mathrm{NaCI})$ & - & - & - & - & - & - \\
\hline Lysine (1\% NaCI) & - & - & - & - & - & - \\
\hline Indole production & - & - & - & - & - & - \\
\hline Urea & - & - & - & - & - & - \\
\hline Growth on $0 \% \mathrm{NaCl}$ & - & - & - & - & - & - \\
\hline Growth on $1 \% \mathrm{NaCl}$ & + & + & + & + & + & + \\
\hline Growth on $3 \% \mathrm{NaCl}$ & + & + & + & + & + & + \\
\hline Growth on $6 \% \mathrm{NaCl}$ & + & + & + & + & + & + \\
\hline Growth on $10 \% \mathrm{NaCl}$ & - & - & - & - & - & - \\
\hline Growth on $12 \% \mathrm{NaCl}$ & - & - & - & - & - & - \\
\hline Growth $4{ }^{\circ} \mathrm{C}$ & - & - & - & - & - & - \\
\hline Growth $22{ }^{\circ} \mathrm{C}$ & - & - & - & - & - & - \\
\hline Growth $37^{\circ} \mathrm{C}$ & + & + & + & + & + & + \\
\hline ONPG test & + & - & - & + & + & - \\
\hline
\end{tabular}




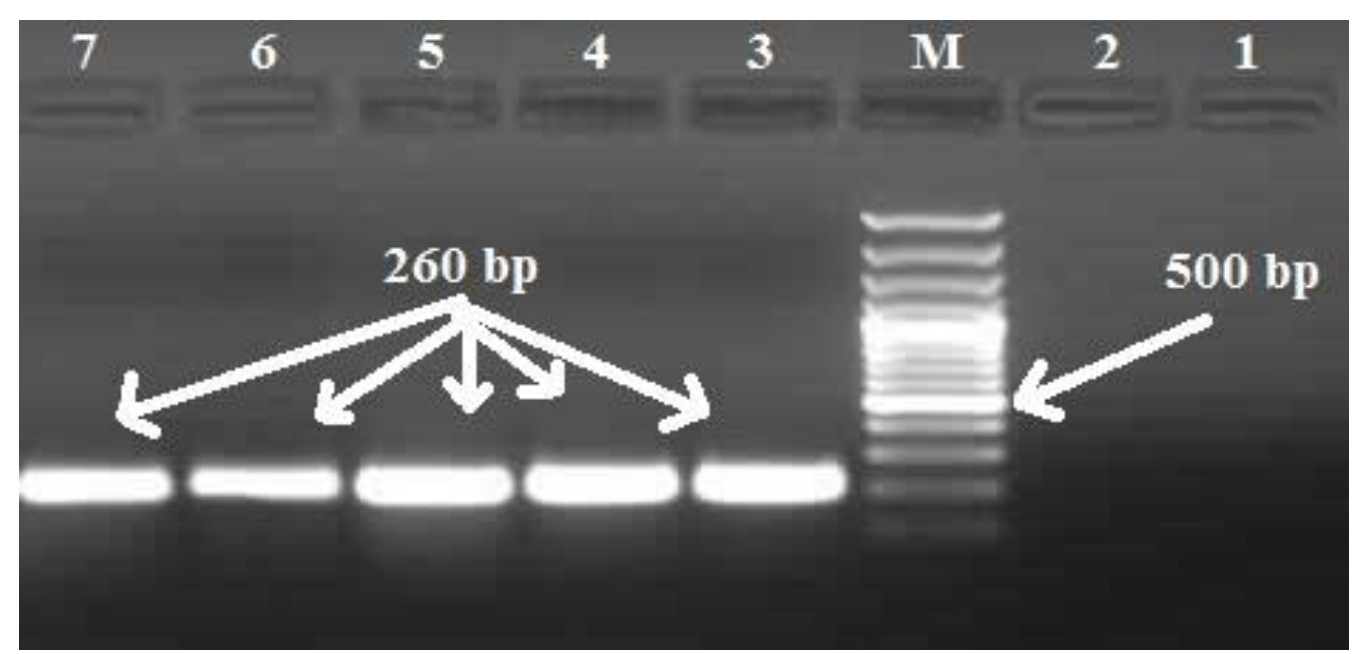

Figure 1. PCR confirmation of V. furnisii isolates. M: Marker, 100bp. Line 1: Negative control Vibrio anguillarum ATCC 19264. Line 2: Negative control, distilled water. Line 3: Positive control V. furnissii ATCC 35016, 260bp. Line 4-7: Isolates (MR1, 2, 3, 4), 260bp.

Şekil 1. V. furnissii izolatlarının PCR ile doğrulanması. M: Marker, 100bp. Hat 1: Negatif kontrol Vibrio anguillarum ATCC 19264. Hat 2: Negatif kontrol, distile su. Hat 3: Pozitif kontrol V. furnissii ATCC 35016, 260 bp. Hat 4-7: İzolatlar (MR 1, 2, 3, 4), 260 bp.

Still, recent reports have shown a higher potential for $V$. furnisii to be a food pathogen $(10,21)$. Therefore, isolation of $V$. furnisii from bivalve molluscs has increasing importance in terms of human health.

Amin et al. (2), in a work with 225 shellfish, 20 channel water and fecal swab samples from diarrhei patients have been isolated V. parahaemolyticus $(2.6 \%)$, V. vulnificus (6.6\%), V. fluvialis (12\%), V. hollisae (2.6\%), V. furnissii (6.6\%), V. mimicus (6.6\%), V. alginolyticus $(10.6 \%)$ and $V$. damsella $(9.3 \%)$. In this work, V. furnissii isolation rate was $0.92 \%(6 / 652)$. This isolation rate was lower than Amin et al. (2). The reason for this, only shellfish were investigate in this work. $V$. furnissii may be isolated from human feces at a high rate (2, 10, 22). V. furnissii isolation from bivalve molluscs may also indicate fecal contamination in the sea. Still, more important parameters such as coliform count should be addressed before reaching a conclusion.

$V$. furnissii isolation rates were found by Amin et al. (2) to be $6.6 \%$ in shrimps and 6\% in oysters whereas Sung et al. (29) found $V$. furnissii isolation rate to be $15 \%$ in shrimps in Taiwan. V. furnisii isolation rates in this work were found to be lower than both; mediterranean mussel $(3.33 \%)$, bearded mussel $(3.27 \%)$, oyster $(3.27 \%)$, clam $(0 \%)$, cockle $(0 \%)$, wedge shell $(0 \%)$, striped venus $(0 \%)$. This might be due to the other members of Vibrio genus being more common in shellfish in Turkey. Previous research has revealed $V$. alginolyticus (5) and $V$. parahaemolyticus $(30,32)$ to be the dominant species.

V. furnisii may also cause infections in shellfish (3, 24). Still, research has shown that bacterial agents affect bivalve molluscs mostly during the larval stage. Among pathogenic Vibrio that affect shellfish; V. alginolyticus, $V$. anguillarum, V. splendidus, V. tapetis, V. tubiashi are foremost (26). Tubiash (31) found that $V$. anguillarum (strain ATCC 1909, concentrations between $10^{6}$ and $10^{7}$ cells in $1 \mathrm{ml}$ ) is highly pathogenic to experimentally infected bivalve larvae, causing 90\% mortalities after 48 hours. Important bacterial agents that affect mature shellfish are within Rickettsia, Chlamydia and Mycoplasma genus $(6,15,26)$. In this work, no outbreaks were reported from sampling stations. This might be an indication of stocks being healthy or due to the difficulty larval diseases of shellfish.

On the other hand, phenotypic characteristics of $V$. furnissii isolates obtained in this work are compatible with other reports $(8,13,16)$. Although isolates were mostly homologous in terms of phenotypic characteristics, when ONPG results are taken into account, at least two may be considered to be of different phenotypes. All isolates were positive for gas production from glucose, therefore easily differentiated from $V$. fluvialis.

\section{References}

1. Ahsan CR, Hoque MM, Rasul Z, et al. (1992): Enterotoxicity of Vibrio furnissii isolated from eels. World J Microbial Biotech, 8, 187-189.

2. Amin MAM, Rizk EGW, Mohamed TS (2011): Occurrence of some zoonotic Vibrios in shellfish and diarrheic patients with regard to tdh gene in Vibrio parahaemolyticus. J Am Sci, 7, 449- 459.

3. Austin B (2010): Vibrios as causal agents of zoonoses. Vet Microbiol, 140, 310-317.

4. Austin B, Austin DA (1999): Vibrionaceae representatives: Characteristics of the disease. In: Bacterial Fish Pathogens: Disease of Farmed and Wild Fish. Springer-Praxis, Chichester 29-30, 108-115. 
5. Avsever ML (2016): First report of trh positive Vibrio alginolyticus isolates from bivalve molluscs in Turkey. Revue Méd Vét, 167, 65-70.

6. Azevedo C, Villalba A (1991): Extracellular giant rickettsiae associated with bacteria in the gill of Crassostrea gigas (Mollusca, Bivalvia). J Invertebr Pathol, 58, 75-81.

7. Baumann P, Baumann L, Woolkalis MJ, et al. (1983): Evolutionary relationships in vibrio and Photobacterium: A basis fora natural classification. Annu Rev Microbiol, 37, 369-398.

8. Brenner DJ, Hickman-Brenner FW, Lee JV (1983): Vibrio furnissii (formerly aerogenic biogroup of Vibrio fluvialis), a new species isolated from human feces and the environment. J Clin Microbiol, 61, 437-467.

9. Chakraborty S, Nair GB, Shinoda S (1997): Pathogenic vibrios in the natural aquatic environment. Rev Environ Health 12, 63-80.

10. Dalsgaard A, Glerup P, Høybye LL, et al. (1997): Vibrio furnissii isolated from humans in Peru: A possible human pathogen. Epidemiol Infect, 119, 143-149.

11. Demir Y (2012): Türkiye'de ihraç edilen Bivalve türlerinden Vibrio türlerinin izolasyon ve identifikasyonu. Etlik Vet Mik Derg, 23, 1-8

12. Espineira M, Atanassova M, Vieites JM, et al. (2010): Validation of a method for the detection of five species, serogroups, biotypes and virulence factors of Vibrio by multiplex PCR in fish and seafood. Food Microbiol, 27, 122131.

13. Esteve C, Amaro C, Biosca EG, et al. (1995): Biochemical and toxigenic properties of Vibrio furnissii isolated from a European eel farm. Aquaculture, 132, 81-90.

14. Furniss AL, Lee JV, Donovan TJ (1977): Group F, a new Vibrio? Lancet, 2, 565-566.

15. Ghadersohi A, Owens L (1999): Isolation, characterisation and DNA analysis of Mycoplasma spp. from moribund prawns Penaeus monodon cultured in Australia. Dis Aquat Org, 35, 53-61.

16. Hickman-Brenner FW, Brenner DJ, Steıgerwalt AG, et al. (1984): Vibrio fluvialis and Vibrio furnissii isolated from a stool sample of one patient. J Clin Microbiol, 20, 125-127.

17. Igbinosa EO, Okoh AI (2008): Emerging Vibrio species: An unending threat to public health in developing countries. Res Microbiol, 159, 495-506.

18. Krieg NR, Holt JG (1984): Bergey's manual of systematic bacteriology, vol. Williams \& Wilkins, Baltimore. Md.

19. Lee JV, Shread P, Furniss AL, et al. (1981): Taxonomy and description of Vibrio fluvialis sp. nov. (synonym group F Vibrios, group EF-6. J Appl Bacteriol, 50, 73-94.

20. Lux TM, Lee R, Love J (2011): Complete genome sequence of a free-living Vibrio furnissii sp. nov. strain (NCTC 11218). J Bacteriol, 193, 1487-1488.

21. Lux TM, Lee R, Love J (2014): Genome-wide phylogenetic analysis of the pathogenic potential of Vibrio furnissii. Front Microbiol, 5, 435.

22. Magalhaes V, Castello Filho A, Magalhaes M, et al. (1993): Laboratory evaluation on pathogenic potentialities of Vibrio furnissii. Mem Inst Oswaldo, 88, 593-597.
23. Mathur J, Waldor MK (2004): The Vibrio cholerae ToxRregulated porin OmpU confers resistance to antimicrobial peptides. Infect Immun, 72, 3577-3583.

24. Matte GR, Matte MH, Rivera ING, et al. (1994): Distribution of potentially pathogenic Vibrios in Oysters from a tropical region. J Food Prot, 3-1, 870-873.

25. Myatt DC, Davis GHG (1989): Extracellular and surfacebound biological activities of Vibrio fluvialis, Vibrio furnissii and related species. Med Microbiol lmmun, 178, 279-287.

26. Renault T, Cochennec N (1995): Chlamydia-like organisms in ctenidia and mantle cells of the Japanese oyster Crassostrea gigas from the French Atlantic coast. Dis Aquat Org, 23, 153-159.

27. Schirmeister F, Dieckmann R, Bechlars S, et al. (2013): Genetic and phenotypic analysis of Vibrio cholerae non-O1, non-O139400 isolated from German and Austrian patients. Eur J Clin Microbiol Infect Dis, 33, 767-78.

28. Schirmeistera F, Wieczoreka A, Dieckmanna R, et al. (2014): Evaluation of molecular methods to discriminate the closely related species Vibrio fluvialis and Vibrio furnissii. Int J Med Microbiol, 304, 851-857.

29. Sung HH, Hsu SF, Chen CK, et al. (2001): Relationships between disease outbreak in cultured tiger shrimp (Penaeus monodon) and the composition of Vibrio communities in pond water and shrimp hepatopancreas during cultivation. Aquaculture, 192, 101-110.

30. Terzi G, Büyüktanır Ö, Yurdusev N (2009): Detection of the tdh and trh genes in Vibrio parahaemolyticus isolates in fish and mussels from middle black sea coast of Turkey. Lett Appl Microbiol, 49, 757-763.

31. Tubiash HS, Otto SV, Hugh R (1973): Cardiac edema associated with Vibrio anguillarum in the American oyster. Proc Natl Shellfish Assoc, 63, 39-42.

32. Türk N, Avsever ML, Ün C (2011): Investigation of tdh and trh genes in Vibrio parahaemolyticus isoletes from isolated Bivalve molluscs. Bor Vet Bil Der, 33, 29-36.

33. Wieczoreka A, Dieckmanna R, Taureck K, et al. (2014): Evaluation of molecular methods to discriminate the closely related species Vibrio fluvialis and Vibrio furnissii Falko Schirmeistera. Int J Med Microbiol, 304, 851-857.

34. Wu TK, Wang YK, Chen YC, et al. (2007): Identification of a Vibrio furnissii oligopeptide permease and characterization fits in vitro hemolytic activity. J Bacteriol, 189, 8215-8223.

Geliş tarihi: 28.12.2015 / Kabul tarihi: 22.06.2016

Address for correspondence:

Dr. Meriç Lütfi Avsever

Aksaray University,

Eskil Vocation of High School,

Laboratory and Veterinary Sciences, 68800, Eskil

Aksaray, Turkey.

e-mail:lutfiavsever@gmail.com 